\title{
ILLIBERAL DEMOCRACY: THE CASE OF DEMOCRATIC EROSION
}

\begin{abstract}
AMY CAMPBELL
Abstract

This paper uses Israel's 2018 Nation-State Law, which guarantees the "ethnic-religious character of Israel as exclusively Jewish," as a lens to reveal the ongoing socio-political change in Israel and processes of democratic erosion. In addition to having immediate relevance for contemporary Israeli policy, especially concerning the status of Arab Israelis and the likely annexation of the West Bank, the law poses a profound, existential challenge for the maintenance of Israel as a democratic state. Drawing on Fareed Zakaria's theory of "illiberal democracy," this paper analyses the implications of this law for Israel, for the linked concepts of liberalism and democracy, and for the future of the democratic state in an increasingly illiberal world.

The law is a culmination of other basic laws and political thresholds, and accelerates settler colonialism. Gaining more international attention than previous basic laws, the political thresholds prior to the Nation-State Law and cumulative legislation building up to the debate have been ignored. Analysing these thresholds will reveal the efficacy of supporting such a law and using nationhood provisions in other Western democratic constitutions as justification. This paper is a warning: to act upon seemingly insignificant anti-democratic legislation before political actions become irreparable.
\end{abstract}

\section{Introduction}

I srael's thirteenth Basic Law, the Nation-State Law, was passed with a slim 62-55 majority and two abstentions on 19 July 2018 (IATF, 2018). The Nation-State Law guarantees the "ethnic-religious character of Israel as exclusively Jewish" and applies to areas west of the "Green Line" where nearly twenty percent of the population are Palestinian citizens of Israel, as well as to the territories occupied in 1967 (Adalah, 2018). It defines Israel solely as a Jewish state, and has concrete policy ramifications as well as further dividing Israeli identity. Immediately after the law was passed, 30,000 protestors opposed the Nation-State Law at an Arab-led rally in Tel Aviv (Pileggi, 2018).

In the attempt to redefine citizenship, the Nation-State Law reaches the core of Israeli conceptions of democracy. The law does not stand alone, and it is not unique in its attempt to strengthen Jewish identity with material consequences. By elucidating the unconstitutional, discriminatory, and geographically significant aspects of the law, I will demonstrate that the law perpetuates a much longer history of illiberal democracy, even as it also stands out as an eventful milestone. To develop this point, I will develop two key concepts that will underpin my analysis: the concept of "illiberal democracy" and the concept of the "threshold." The concept of illiberal democracy, which was popularised by Fareed Zakaria (1997) in a widely cited Foreign Affairs 


\section{Columbia Undergraduate Research Journal}

article and subsequently expanded upon in his book The Future of Freedom (2007), suggests that its two constitutive terms - illiberalism and democracy - although seemingly at odds with each other, are in fact increasingly applied together. I will suggest that the Nation-State Law can be understood as an application of this trend. The second concept, the threshold, establishes the basis for understanding an event as, on the one hand, unremarkably continuing past trends while, on the other hand, having dramatic consequences. I will suggest that this term, as well, can shed light on the significance of the Nation-State Law.

To develop this argument, I draw upon data from 17 interviews conducted with human-rights lawyers, Israeli and Palestinian politicians, NGO leaders, and academics (See Appendix, Table 1). These interviews were conducted between the 30th June 2019 and 18th July 2019 in Tel Aviv, Jerusalem, and the Occupied Palestinian territories. Each interview lasted between 30 minutes and one hour, and semi-structured interviews were used to gain a consistent understanding of the law in the context of the interviewee's personal experiences and positions. Because individuals held public positions, all agreed to be identified by name and quoted.

Recent profusions of scholarly work on the Nation-State Law further demonstrate that this analysis is timely and relevant in understanding the increase in illiberal democracy. The publishing by Israeli Studies is dynamic in its scoping of the narratives and debates on the law (Kontorovich, 2020; Yakobson, 2020) and in its diagnosis of the main controversies that the law unleashed. However, I argue that this profusion of literature does not forward the qualitative points at which constitutional liberalism fades. I will introduce the concept of the threshold in order to investigate why these debates continue past trends, and move past debates to present the argument for how illiberalism results from the loss of constitutional liberalism. I argue that through the layered implications of legislation, infringing upon human rights incrementally, this leads to concrete discrimination and the erosion of democracy through the political threshold.

\section{Fareed Zakaria: Beyond Illiberal Democracy}

Since the publication of Zakaria's 1977 foreign affairs article, illiberal democracy has been extensively debated in political, international relations, and geographical literature. A key tenet of Zakaria's argument is that democratic process, as an electoral democracy, does not lead to increased liberty. Electoral democracy leads to poor governance, increases instability, places ethnic minorities at risk, and legitimises efforts to suppress political opponents. Constitutional liberalism is "not about the procedures for selecting government, but rather government's goals" (Zakaria, 1997, p.25) and Zakaria argues we need to revive constitutionalism. It is argued that Zakaria is perhaps shortsighted in his definition of democracy as "purely electoral" (Moller, 2008, p.556) and that he uses a one-dimensional classification to 


\section{Columbia Undergraduate Research Journal}

identify "democratizing" states. The trajectory Zakaria outlines is linear; the trajectory of illiberal democracy "starts with constitutional liberalism and then moves only towards free elections" (p.557). Karatnycky (1999) conversely argues that there are signs that electoral democracy does indeed have a positive effect on freedom and that "88 electoral democracies...successfully protect a broad range of political and civil rights” (p.2). Elections often do form a crucial step in the process of attaining political legitimacy, but we must be vigilant in understanding when democratic process is a vehicle towards illiberalism.

Democracy, as a palimpsest of political thresholds, is often eroded incrementally. Though accurate in his observation that illiberal democracy is on the rise, "Zakaria misses the mark in explaining why and in prescribing what to do about it" (Kapuchan, 1998, p.122). Zakaria is also approaching illiberal democracy from a US perspective, and liberalism has only preceded democracy in the Anglo-Saxon West. Applying these concepts in regions that have "little or no experience in constitutional liberalism" (Kupuchan, 1998, p.122) has the potential to be highly valuable in understanding how social power is undermined incrementally. Illiberal democracies are growing in ways that aren't obvious, which is why I introduce the political threshold concept. Democracy requires long-term assistance, in a wide variety of ways: to foster the growth of civil society, basic freedoms, the rule of law, and democratic culture. Zakaria made illiberal democracy easily accessible in a foreign policy and international affairs context, and it is possible to take his core principles and analyse them in a nuanced way within the Israeli political system and other nation-states.

\section{Critical Legal Studies: Illiberal Democracy and the Threshold}

Critical legal studies have "undermined the central ideas of modern legal thought" and put "another conception of law in their place" (Unger, 1983, p.563). It is a critique of formalism and objectivism, and recognises that law-making is the result of "social life" (ibid). I will draw upon critical legal studies to place Zakaria's central tenet, the separation of democracy and constitutional liberalism, in the context of tangible qualitative change in social power and liberty. Critical legal studies understand that within liberal democratic societies the government must "constantly intervene in the arrangements of this social world" (p.606), through law making.

I will separate democracy as a term, as a political process versus liberalism as social power and opportunity, in order to understand democratic erosion and the rise of illiberalism. Before connecting the passing of the Nation-State Law with illiberal democracy more broadly, I will use Zakaria (1997) to define democracy, constitutional liberalism, and the separation of constitutional liberalism and democracy qualitatively undermining social power. To diagnose illiberal democracy, I have to decide the point at which qualitative change (as democratic erosion) occurs. This is where I believe the concept of the threshold is vital. Kimmerling (1989) used the concept of "Framework 


\section{Columbia Undergraduate Research Journal}

Decisions" to diagnose the boundaries within what he calls the "Israeli Control System." Kimmerling maps out what I believe is the threshold for illiberal democracy, defined by: the unit of analysis or "proper territorial-political unit to be analysed" (p.5), the definition of democracy, and periodisation of that democracy. These points are decided within the Israeli "social system" (p.266). He argues that "social boundaries" are often "cultural, political, economic, stratificational, ethnic, national" (p.268). In my diagnosis, I define the unit of analysis as the constitutional rights Arab minorities have within the Israeli system. In terms of periodisation, I draw on Feinstein and Eliezer's (2018) scoping of Israel's “rapid decline into illiberal nationalism” (p. 569) from Israel's neoliberal phase (mid-1980s to early 1990s) to the rise of prominent illiberal ethnonationalism (mid-1990s to the present). When defining democracy, Zakaria argues democracy within an illiberal democratic context refers to political process, whereas I am more concerned about social power. Shapiro (1997) was arguably the first Israeli social scientist to implement this framework of the threshold constitutionally, making the distinction between "substantive" (i.e liberal) democracy and "formal" (i.e procedural) democracy. Israel may meet the procedural definition of democracy, but Israel's ethnic democracy can currently only be sustained by the "confluence of two constitutional principles: liberal democracy and Jewish ethno-nationalism" (Peled and Navot, 2005, p.7). I echo ethnocratic scholarship, that the Jewish majority has been consistently prioritised constitutionally (Peled, 2014; Smooha, 1990; Yiftachel, 2000). I use the threshold to understand this confluence. Building upon these conceptions of the threshold, I will anchor the point at which I believe social power has been lost (crossing the threshold).

Democracy refers to political process rather than the power citizens of a nation-state have. This democratic process is the most tangible means of recognising a democracy. The ways in which elections are conducted are supposedly "open, free and fair...the essence of democracy" (Huntington, 1991). Even so, governments produced by elections may be "inefficient, corrupt, short-sighted, irresponsible, dominated by special interests and incapable of adopting policies demanded by the public good" (ibid). To place weighting on procedural democratic process (i.e. elections) ignores governmental decisions and how power is disseminated within a country. By contrast, liberalism is about opportunity and social power. It is necessary to interrogate constitutional liberalism within the "government's goals" (Zakaria, 1997, p.25) rather than merely democratic procedure. Constitutional liberalism exists to "protect an individual's autonomy and dignity against coercion" (p.25). It is liberal because it "emphasizes individual liberty" (p.26) and constitutional because it depends on the "rule of law" (p.26). The tension between democracy and constitutional liberalism is that democratic process is likely to accelerate illiberalism within the scope of "governmental authority" (p.30). Without the background of constitutional liberalism in an ethnically divided society this can foment "nationalism, ethnic conflict, and even war" (p.35). Social power can be undermined even when political process 


\section{Columbia Undergraduate Research Journal}

seems intact. Illiberal democracy is a "growth industry" (p.24) and the "process of genuine liberalization and democratization is gradual and long-term, in which an election is only one step" (p.40). In order to understand how social power is undermined, the political threshold is a vehicle for accelerating illiberal democracy. Zakaria describes this as a "constitutional limit" (p.22), but qualitative changes are needed to put constitutional, civil and political rights at risk.

The 2018 Nation-State Law places the threshold of illiberalism in context, an example of routinely ignoring liberal constitutional thresholds. The political threshold is when the citizen of a nation-state does not have the opportunity, social power, and freedoms that constitutional liberalism should provide.

\section{The Nation-State Law in Context II}

The law contains eleven sections, though this paper cannot possibly explore all sections in depth: "Basic Principles," "The Connection with Jewish People," and "Jewish Settlement" (Knesset, 2018) are most vital in understanding Israel's conception of defining an ethnocracy, with explicit examples of political thresholds. Incremental provisions set thresholds for further illiberal legislation and reflect a longer history of illiberal democracy. The law declares that Israel is a Jewish state only and is the "national home of the Jewish people" (Knesset, 2018). The law contradicts international law, holds discriminatory implications, and enacts material geographic consequences.

The deliberate omission of equality is a crucial political threshold accelerating illiberalism. To briefly give historical context, the antagonisms manifesting in the passing of the law were grounded in the 1992 constitutional revolution in Israel. Ruth Gavison was appointed in 2013 by Justice Minister Tzipi Livni to lead a commission to formulate the Nation-State Law, which was viewed as a means of protecting the Jewish majority (Peled and Navot, 2005; Smooha 1990). Arab-Israelis currently make up more than 20 percent of the population. The law was a calculated political manoeuvre to alter the balance between protecting the Jewish majority and maintaining democracy. Altering this balance was an example of removing liberalism and maintaining democratic political process (Zakaria, 1997). The tension arose in 1992 with the failed initiation of a constitution, and two laws were passed by the Knesset relating to human rights including "Basic Law: Human Dignity and Liberty" (Knesset, 1992) to compensate. This law, under Prime Minister Rabin, declared that the fundamental human rights in Israel are founded upon the recognition of the "value of the human being." Antagonistically, this Basic Law was interpreted as giving the power of judicial review over Knesset Laws. Yet, as Ameer Fakhourym, a Palestinian citizen of Israel and the head of the School for Peace Research Centre at Wahat alSalam-Neve Shalom, highlighted in interview, "the right for equality in 1992...does not include equality" (Fakhourym, interview,11.07.19). Amir Fuchs, the head of the 


\section{Columbia Undergraduate Research Journal}

Defending Democratic Values Program at The Israel Democracy Institute, stated that "his is what happens when you don't have a constitution" (Fuchs, interview, 16.07.19). The context of the constitutional revolution, an example of removing constitutional liberalism and crossing political thresholds, highlights this accelerated illiberalism.

Other laws touching upon equality have masked the crossing of illiberal political thresholds, skating close enough to liberalism to evade criticism. As Amir Fuchs implores "there is no [democratic] country in the world that has not specifically enumerated the right of equality in its constitution" (Fuchs, interview, 16.07.19). The Human Dignity and Liberty law is not equivalent, and the Nation-State Law is seen as a culmination of other basic laws (IATF, 2018). The law imposes a constitutional identity on the Arabs without their consent and creates a political space in which the Arabs participate under coercion. This contradicts the United Nations Assistance to Constitution-making processes (UN, 2009). To place this omission in an international context: Ecuador's 2008 constitution initially containing equality and democracy was eroded, Hungary was subject to Fidesz dictating the court's mode of operations, Poland was undermined by a series of legislative changes, and Venezuela and Russia systematically enabled constitutional amendments to undermine democracy (Loughlin, 2019). This erosion was intentional, Justice Minister Ayelet Shaked proposed Israel must administer "equal civil" but not "national rights" (Hovel, 2018). It is increasingly clear that Israel latches onto political process, actively pushing away social power for all citizens and moving further into the illiberal democratic sphere.

The balance between ethnicity and democratic values became a significant political threshold in the passing of the law. The law states that only the Jewish people in Israel have the "natural, cultural, religious and historical right to self-determination" and that the "exercise of the right to self-determination in the State of Israel is unique to the Jewish people" (Knesset, 2018). Ironically, Cummings (Deputy minister in the Prime Minister's Office) argued in interview that a primary foundation of Israel is that "our democracy remains robust and steadfast" (Cummings, interview, 17.07.19). As Jeff Halper, former Director of the Israeli Committee Against Housing Demolitions, articulated in interview, the courts were as a result "instructed not to judge a case by its own merits...but according to how it serves the Zionist purpose" (Halper, interview, 16,07.19). The law states in Article XIII that when a dispute in court cannot be resolved by "existing statute, by judicial precedent, or by strict legal analogy" that it will be resolved using "Jewish civil law" (Mossawa, 2017, p.3). Reflected by the outcry from Israeli human rights organisations, the law unequivocally "violates absolute prohibitions under international law" (Adalah, 2018). Adalah even restated their concerns in the recent publication by Israeli Studies (Adalah, 2020). Mossawa, the advocacy centre for Arab Citizens in Israel, highlights that the law directly contradicts international human rights law. The provision guaranteeing the right to national selfdetermination only to Jewish People "contradicts Article One of the International Covenant on Civil and Political Rights, to which Israel is signatory" (Mossawa, 2017, 


\section{Columbia Undergraduate Research Journal}

p.1). This omission in granting self-determination to both Jews and Arab-Israelis reflects the longer struggle between balancing Jewish identity and democracy within Israel.

There are direct material geographical implications included in the law. Jewish settlement is encouraged: the second provision of Article IX is that the state "views the development of Jewish settlement as a national value, and shall act to encourage and promote its establishment" (Knesset, 2018). According to Mossawa, this "defies the International Convention on the Elimination of All Forms of Racial Discrimination" (Mossawa, 2017, p.2). High Court President Miriam Naor "refused to reconsider" the planned demolition of Umm al-Hiran, a Bedouin village in the Naqab (Negev) in order to build a Jewish one (Iraqi, 2017). While interviewing Amir Fuchs, he expanded upon the Kadan versus Israel Lands Authority case: an Israeli Arab couple who wanted to build their house in the settlement of Katsir in Israel. Their request was rejected as they were Arabs and the land was designed exclusively for Jews. Similarly, the 1924 Afula affair demonstrated real land struggles caused by "illegitimate colonial settlement" (Locker-Biletzki, 2018, p.395). Fayrouz Sharqawi shed light on the contemporary rejection of Palestinian building permits in East Jerusalem: "Israel rejects around 94\% of peoples applications for building permits... Israel does not allow the Palestinians to build" and homes are consequently demolished (Sharqawi, interview, 15.07.19). The Israeli use of the British Mandate planning legacy has long been used as a tool for the control of Palestinians in the West Bank (Khamaisi, 1997). Hagai El-Ad, serving as the director general of B'Tselem, spoke at the United Nations

Security Council in 2018: "It is a calculated and deliberate process of slowly splitting up an entire people" and "none of it is in fact legal, or moral, or even remotely acceptable.” El-Ad highlights, Israel is “oppressing millions while somehow still being considered a democracy" (Btselem, 2018). The "façade of legality" has been successful at evading "any real international consequences" (Btselem, 2018); legislation has been consistently and historically used to protect the Jewish majority. There is enough continuity in the law and support from the moderate Jewish left to prevent real outcry at an international policy level. This law has slipped by unnoticed, with the recent threat of annexation subsuming the legal foundations of illiberalism in Israel. These are concrete examples of qualitative change caused by crossing legislative political thresholds (Kimmerling, 1989). Arab citizens materially lost social power as a result of the Nation-State Law.

Most analyses of the law have focused on what its direct implications will be for the civil rights of Arab Israelis and Palestinians in the Occupied Palestinian Territory and the West Bank. I instead look at how the law signals the erosion of constitutional liberalism. The law suspends Israel's domestic legal system, neglecting to base law on equality and international humanitarian law (Adlah, 2018). This law is alarming, and it is vital to explore its journey to being passed. 


\section{Columbia Undergraduate Research Journal}

\section{The Nation-State Law and Illiberal Democracy III}

The law was not simply to define Israel and continue previous discourse; it was a calculated political manoeuvre to alter the balance between protecting the Jewish majority and maintaining democracy in Israel. In altering that balance, Israel pushed towards illiberal democracy. It is essential to understand the passing of the NationState Law as representing the tension between constitutional liberalism and democracy. Briefly, this illiberalism can be applied to innumerable nation-states. Orbán's regime in Hungary is borderline dictatorial, Iran's regime is semi-theocratic, and Modi's Bharantiya Janata party in India continues to reinforce Hindu nationalism. As an ethno-nationalist state (Yiftachel, 2000), Israel has long struggled with the concept of liberal democracy.

Illiberal ethnocratic states are often categorised as theocracies. Gavison (2018) raises the point that to claim the State of Israel is not democratic, the claim must therefore be that Israel is a theocracy. This division misses the illiberal political thresholds between a democracy and theocracy; this doesn't reflect how constitutional liberalism is lost within democratic process. The Nation-State Law, including the processes behind it and following it, violates the human rights of minorities living in Israel as an ethno-nationalist state. The "violation" (Gavinson, 2018) is complex to define, as the violations of the Nation-State Law are both material and symbolic. The struggle within an ethno-nationalist state comprises two layers. Firstly, an ethnic "nation-state cannot give its minorities a full sense of membership and belonging, because part of that membership is...connected to the history and the culture of the majority" (Gavison, 2014, p.150). A nation-state inherently means all citizens cannot belong. To maintain a nation-state, exclusion in some way is necessary. Secondly, democracy and equality either exist or not. There is no compromise when it comes to ensuring equality. To fall short is to cause a power imbalance between citizens and communities. Eugene Kontorovich argued that "equality is a broad term of no specific definition" (2020, p.148). This is a dangerous stance to have on a state which has consistently violated international human rights laws. In granting more power to one community, an illiberal threshold has been reached.

The law ultimately did pass, and this support must be closely followed. Supporters argue that similar laws in other Western democracies prove the efficacy of criticism towards the Nation-State Law (Kontorovich, 2020). It is difficult to compare Israel to other nation-states as it does not have a constitution, but a series of basic laws. This context is all the more reason to use Critical Legal Studies, critiquing formalism and objectivism (Unger, 1983). The Nation-State Law defines the State of Israel and is very close to a constitution. Eugene Kontorovich, an avid supporter of the law from the Kohelet Policy Forum, argues that several EU states have constitutional "nationhood" provisions such as Latvia, Slovakia and Spain. In Spain, the Spanish nationality is prioritised over ethnic minorities such as the Basques of the 


\section{Columbia Undergraduate Research Journal}

Catalans, and in Europe, France and Germany both emphasise self-determination. This doesn't hold water (at least constitutionally), as section 2 of the Spanish constitution of 1978 stipulates that Spain "recognises and guarantees the right to selfgovernment of the nationalities and regions of which it is composed and the solidarity among them all" (SC, p.10). All basic laws are weighted the same in court. Yet, the Nation-State Law is clearly the basic law which defines what it means to be a citizen in Israel.

Supporters also distinguish between collective and individual rights. Eugene Kontorovich argues that other Western liberal democracies accept the particularistic communal identity of their national majority, and that the law does not change any pre-existing individual rights, but only collective provisions (Peleg, 2020). Avi Dichter from Likud who proposed the law, argued it was a direct defence response to efforts to transform Israel to a country of all its citizens (Dunst, 2018), and thus as a response to the growing Arab population. The law does not allow for self-determination of any other community inside Israel. Self determination "as a nation is unique to Jews" (Fuchs, interview, 16.07.19). Cummings argued that "national self determination is only available to Jewish citizens" but the "national identity" of Israel is more “cosmopolitan” (Cummings, interview, 17.07.19). Eli Hazan, Foreign Affairs Director of the Likud Party, anchored the reasoning behind the law as simply to define Israel as being a "state for the Jews" (Hazan, interview, 17.07.19). I draw on my interview with Ameer Fakhoury: "either there is full equality or not" (Fakhoury, interview, 11.07.19). Ardent proposers of the law entirely neglect to recognise equality and inclusivity as key pillars of an active democracy; adopting an international and historical perspective, the law is inherently wrought with contradictions of Zionism. Jonathan Cummings, adviser to the deputy minister in the Prime Minister's Office, said in interview, "it's saying that national self-determination is only available to Jewish citizens" (Cummings, interview, 17.07.19), and Ofir Haivry, vice president at the Herzl Institute, said: "it doesn't mean that anyone is a second-class citizen...every citizen deserves individual rights but not every minority has national rights" (Haivry, interview, 10.07.19). Interviewees agreed that the Nation-State Law prioritised the Jewish people, yet this agreement did not extend to recognising the movement towards illiberalism. It is "difficult to justify defining self-determination for only one group of citizens when you claim to be a democracy," said Dahlia Scheindlin, political analyst and writer for Haaretz (Schiendlin, interview, 02.07.2019). The supporters of the Nation-State Law prove in Zakaria's terms that, under the illiberal democratic phenomenon, the "problems of governance in the 21 st century will likely be 'problems within democracy"' (Zakaria, 1997, p.42). Thus, to understand the support behind the Nation-State Law means to understand how liberalism is undermined.

The Israeli left is the only opposition in Israel with enough backing to enact real change, and without radicalism and structural reform, illiberal democracy will continue unabated. Another struggle is within the Israeli left wing. Debbie Gild-Hayo, 


\section{Columbia Undergraduate Research Journal}

Director at the Association for Civil Rights in Israel (ACRI), said that "we petitioned against it, so we can work to try and amend it" (Gild-Hayo, interview, 05.07.19), but this is not trying to eradicate it entirely. This is the first problem -- the assumption that because a country was founded as a democracy, it will indefinitely continue as a democracy. Zakaria, quoting Philippe Schmiter, wrote, "Liberalism...may have coincided with the rise of democracy. But it has never been immutably or unambiguously linked to its practice" (Zakaria, 1997, p.23). Ameer Fakhoury argues there is a deadlock in the Israeli left: whether or not to accept Israel as both a Jewish and democratic state. This was abundantly clear in my interviews: some Israeli human rights organisations paradoxically swore by Israel as Jewish and democratic. Instead of turning to Jewish centrist parties to push for change, "the Jewish left should turn to the Palestinian parties within Israel" (Fakoury and Manekin, 2019). The majority of Palestinian Arab Israelis don't believe the Jewish and democratic model is even remotely inclusive.

\section{Illiberal Legislation IV}

The Nation State Law is not one isolated piece of legislation, repeating Scheindlin's words: “We see a whole enormous scope of not only laws: bills, government policies, discourse, delegitimization of all parts of the democratic system in Israel" (Scheindlin, 02.07.19). The erosion of democracy is well documented in Adalah's database of over 65 Israeli laws that discriminate "directly or indirectly against Palestinian citizens in Israel and/or Palestinian residents of the Occupied Palestinian Territory (OPT) on the basis of their national belonging” (Adalah, 2017). There has been an erosion of democratic values within legislation, specific incidents, ministerial decisions, bills passed, and bills in discussion from the eighteenth to twentieth Knesset.

I argue that illiberal legislation must be examined from previous bills and discussions which circulated in the political system. Beginning with the eighteenth Knesset, elected in 2009, the NGO "Transparency" law meant NGOs had to disclose all funding sources publicly, specifically applied to human rights groups critical of government policy (UN, 2016). This affected B'Tselem, Peace Now, and Yesh Din, major Israeli left human rights organisations (Beaumont, 2016). There were a series of illiberal pieces of legislation passed in the nineteenth Knesset (2009-2013). Notably, the "Boycott Law" called for the nonviolent form of political expression to be a civil offence (ACRI, 2018) as part of the shrinking democratic space in Israel. This is a direct infringement on freedom of expression (ACRI, 2018), and an attack on the institutions that make up the democratic structure in Israel. The bill impairs public discussion on urgent and controversial issues, violating constitutional rights to the freedom of expression, dignity, and equality. Materially, the bill prohibited persons who support a boycott against Israel from entering the state by denying a visa entry as well as being called to pay compensation of NIS 100,000 (Gild-Hayo, 2018). The High

VOL $5 \mid 10$ 


\section{Columbia Undergraduate Research Journal}

Court of Justice rejected ACRI's petition on the infringement on freedom of expression. In 2011 the "Admissions Committee Law" allowed discrimination against Arabs wishing to live in small residential Jewish communities. Admissions committees are authorised by Israeli law to reject applicants for residency; Palestinian citizens and other marginalised groups are rejected solely on the basis of their race, ethnicity, religion, or other identity. Research conducted by the Knesset Research and Information Centre reveals at least 24 communities in the Galilee and Negev regions continue to operate admissions committees despite having found more than 400 households (Adalah, 2019).

The "Loyalty in Culture" bill, a preface to the "Nakba Law" in 2011, allowed ministers to disqualify government funding of institutions that "express political positions contrary to the political majority" (Gild-Hayo, 2018, p.30). State funds were conditional on content that Israel's political authorities deemed loyal to the state (Wootliff, 2018). The following Nakba Law, an amendment to the Budget Fundamentals Law of 2011, declared that any public institution observing the Nakba would lose public funding (Adalah, 2011). This authorised the Minister of Finance to reduce funding or support provided by the state to an institution if it holds an activity that contradicts the definition of the State of Israel as "Jewish and democratic." The Israeli Supreme Court rejected a petition brought against the Nakba Law by Adalah (2016) and the Association for Civil Rights in Israel (ACRI). This continued throughout the twentieth Knesset (2015-2019). Rolling back judicial activism, the "Recommendations Law" prevented the police from publishing the findings of their investigations into Netanyahu's corruption cases. Though this law was disqualified, the "Override Bill" was proposed to make it easier for the Knesset to annul a court ruling that says a law is unconstitutional. This was a direct attack on the mechanisms standing to protect democracy in Israel. This "restriction of Standing and giving priority to Jewish Law" (Gild-Hayo, 2018, p.4) would have politicised the Judicial Appointments Committee and caused a substantive split in the Israeli legal system. Had this law passed, it would have revoked the High Court's authority to interfere in legislation by elected officials and turn High Court rulings into non-binding recommendations (Lis, 2019).

These laws are just a few examples of illiberal democratic processes in the Israeli political system from the eighteenth-twentieth Knesset. These laws, though not all passed, represent "ongoing and cumulative damage" (Gild-Hayo, 2018, p.3) in the Israeli legal system. As Cody O'Rourke, Director of The Shepherd Collective, argued, systems of oppression are made of "small building blocks that add up on top of each other" (O’Rourke, interview, 15.07.19). Even if these bills and initiatives were not implemented, "the attempt to advance them...has a considerable chilling effect on Israeli society as a whole" (p.30). The Nation-State Law is a crucial yet small part of a much more complex set of anti-democratic processes. The law was a "slippery slope" in paving the way for "more concrete measures in the future" (IATF, 2018, p.2). The 


\section{Columbia Undergraduate Research Journal}

nation state law didn't curtail anyone's rights immediately, but set a political threshold accompanying material geographical implications.

\section{Conclusion: Illiberal Democracy Beyond the Nation-State Law}

The trend in the erosion of democracy within the Nation-State Law continues (Waxman and Peleg, 2020). There is copious evidence of illiberal democratic processes occurring elsewhere, and a long-term risk to the erosion of liberalism and democracy. Importantly, "none of these laws actually end individual freedom...This moderate approach ensures that such laws pass both legal and public scrutiny, and successfully sidestep accusations of fascism" (Scheindlin, interview, 02.07.19). Illiberal democracies "gain legitimacy, and thus strength, from the fact that they are reasonably democratic" (Zakaria, 1997, p.42). Israel still ranks high on international indices and Freedom House ranks Israel as "free" (Hermann et al, 2018). Yet, the 2018 Israel Democracy Index rating (combining scores from the World Bank and the Economist Intelligence Unit) reveal that Israel has declined on "civil liberties, rule of law, and the perception of corruption" (Hermann et al, 2018). The greatest danger that illiberal democracy poses "other than to its own people -- is that it will discredit liberal democracy itself, casting a shadow on democratic governance" (Zakaria, 1997, p.42). The debate between Jewish and democratic clouds the simplicity of ensuring equality for all citizens.

The most recent coronavirus bill passed by the Knesset, analysed by Amir Fuchs, whom I interviewed during fieldwork, reinforces illiberal democracy. The proposed model for the coronavirus bill, enabling the Knesset to enact regulations without the need for Knesset approval, "distorts the bill's purpose, which is to replace the emergency regulations with "primary legislation"' (Fuchs et al, 2020). The only consequence has been granting the Government "exceedingly broad discretion with regard to the declaration of a state of emergency and the scope of the infringement of human rights which it would sanction" (Fuchs et al, 2020). Further, Israel's illiberalism "continues to the annexation of the West Bank. Alarmingly, Netanyahu is set on ensuring a smaller-scale annexation, perhaps even a symbolic one, just to avoid the appearance of having caved in completely" (Harel and Tibon, 2020).

This is not a conclusion, but rather a warning. Interviewing human rights lawyers, politicians, NGO leaders, and activists demonstrated the far-reaching relevance of one piece of legislation, and the importance of understanding the entire Israeli political system to analyse the process of democracy eroding. Small provisions set thresholds for more damaging legislation. This applies far beyond Israel, to nationstates increasingly separating procedural democracy and constitutional liberalism. We return to Zakaria's (1997) interpretation of illiberal democracy as a widespread phenomenon. Democracy is almost an unhelpful term when analysing one of the most conflict-wrought ethnocracies in the world. A democracy either guarantees equality to 


\section{Columbia Undergraduate Research Journal}

all of its citizens or it doesn't. Allowing a balance, precariously in flux and always subject to political manipulation, is unacceptable. This paper calls for every political actor to be vigilant in recognising incremental movements towards illiberalism as the Western world moves closer towards authoritarianism and populism. As more illiberal bills are passed in supposedly democratic countries, we must ensure liberalism protects opportunity and social power. 


\section{Appendix}

Table 1: List of interviewees and dates of interviews

\begin{tabular}{|c|c|c|}
\hline Interviewee & Position/ Organisation & $\begin{array}{l}\text { Date of } \\
\text { Interview }\end{array}$ \\
\hline Dr. Natalie Davidson & $\begin{array}{l}\text { Human rights lawyer, Tel Aviv } \\
\text { University Faculty of Law }\end{array}$ & $30^{\text {th }}$ June 2019 \\
\hline Daana Talmi & NGO leader- Yahel Israel & $2^{\text {nd }}$ July 2019 \\
\hline Dahlia Schiendlin & Political Analyst- Haaretz, +972 & $2^{\text {nd }}$ July 2019 \\
\hline Avivit Hai & $\begin{array}{l}\text { Program Director- Inter Agency Task } \\
\text { Force of Israel }\end{array}$ & $4^{\text {th }}$ July 2019 \\
\hline Debbie Gild-Hayo & Association for Civil Rights in Israel & $5^{\text {th }}$ July 2019 \\
\hline MK Zvi Houser & $\begin{array}{l}\text { Former cabinet secretary to } \\
\text { Netanyahu }\end{array}$ & $7^{\text {th }}$ July 2019 \\
\hline Ofir Haivry & Vice President at the Herzl Institute & $10^{\text {th }}$ July 2019 \\
\hline Noa Lazimi & $\begin{array}{l}\text { Research Coordinator of the Institute } \\
\text { for Zionist Strategies }\end{array}$ & $10^{\text {th }}$ July 2019 \\
\hline Adi Arbel & Kohelet Forum & $11^{\text {th }}$ July 2019 \\
\hline Ameer Fakoury & $\begin{array}{l}\text { Head of Neve Shalom's School for } \\
\text { Peace Research Centre }\end{array}$ & $11^{\text {th }}$ July 2019 \\
\hline Oded Revivi & $\begin{array}{l}\text { Head of the Efrat Municipal Council } \\
\text { \& Chef Foreign Envoy, YESHA } \\
\text { Council }\end{array}$ & $14^{\text {th }}$ July 2019 \\
\hline Cody O'Rourke & Director of The Shepherd Collective & $15^{\text {th }}$ July 2019 \\
\hline Fayrouz Sharqawi & $\begin{array}{l}\text { Advocacy Coordinator at Grassroots } \\
\text { Jerusalem }\end{array}$ & $15^{\text {th }}$ July 2019 \\
\hline Dr. Amir Fuchs & The Israel Democracy Institute & $16^{\text {th }}$ July 2019 \\
\hline Jeff Halper & $\begin{array}{l}\text { Former Director of the Israeli } \\
\text { Committee Against Housing } \\
\text { Demolitions }\end{array}$ & $16^{\text {th }}$ July 2019 \\
\hline Jonathan Cummings & $\begin{array}{l}\text { Deputy minister in the Prime } \\
\text { Minister's Office (Michael Oren) }\end{array}$ & $17^{\text {th }}$ July 2019 \\
\hline Eli Hazan & $\begin{array}{l}\text { Foreign Affairs Director of the Likud } \\
\text { Party }\end{array}$ & $18^{\text {th }}$ July 2019 \\
\hline Dr. Yael Berda & $\begin{array}{l}\text { Assistant Professor, Hebrew } \\
\text { University; Visiting Professor, } \\
\text { Harvard University }\end{array}$ & $\begin{array}{l}19^{\text {th }} \text { November } \\
2020\end{array}$ \\
\hline
\end{tabular}




\section{WORKS CITED}

ACRI ‘Ongoing Anti-Democratic Legislation' Shrinking Democratic Space in Israel, November 2018; available at: https://www.english.acri.org.il/post/_ [Accessed 12/06/20]

Adalah.org 'The Discriminatory Laws Database', 2017 [online] Available at: https://www.adalah.org/en/content/view/7771 [Accessed 07/06/2020].

Adalah 'Adalah Petition to Israel's High Court of Justice Proposed Basic Law: IsraelThe Nation State' Israel Studies vol 25, no. 3, 2020, pp.229-239

Adalah.org 'Adalah: Nakba Law Violates Rights of Arab Minority to Preserve its History and Culture', 2011 [online] available at: https://www.adalah.org/en/content/view/7181 - [Accessed 07/06/2020].

Adalah.org 'Knesset's Education Committee must reject Culture Minister's bill requiring cultural centres and artists to declare loyalty to the state' 2016 [online] available at: https://www.adalah.org/en/content/view/8741 [Accessed $12 / 06 / 20$

Adalah.org 'Adalah demands Israel cancel illegal 'admissions committees' enforcing segregation in dozens of communities across the country' 2019- Adalah [online] Available at: https://www.adalah.org/en/content/view/9751[Accessed 12/06/20]

Adalah.org. 'Israeli Parliament Votes To Approve Nation-State Law That Enshrines Jewish Supremacy Over Palestinian Citizens' 2018; Available at: https://www.adalah.org/en/content/view/9565 [Accessed 07/06/2020].

Dunst, Charles. 'Jewish? Democratic? Nation-State Law raises questions over Israel's purpose The Times of Israel', 2018, available at : https://www.timesofisrael.com/jewish-democratic-nation-state-law-raisesquestions-over-israels-purpose/ [Accessed, 09/06/20]

Fakhoury, Ameer. and Manekin, Mikhael. 'How the Jewish Left and Palestinian Arabs Can Remake Israeli Politics' Foreign Policy, 2019 available at: https://foreignpolicy.com/2019/01/21/netanyahu-left-palestinian-partieselections/ [Accessed, 07/06/2020]

Feinstein, Yuval. and Ben-Eliezer, Uri., 'Failed peace and the decline in liberalism in Israel: A spiral model' Mediterranean Politics, vol 24, no.5, 2018 pp.568-591.

Fuchs, Amir., Kremnitzer, M., Margalit, L. 'Coronavirus Bill-Professional Opinion Excerpts Israel Democracy Institute', 2020, available at: https://en.idi.org.il/articles/31741 [Accessed 12/06/20]

Guidance Note of The Secretary-General: United Nations Assistance to Constitutionmaking Processes. United Nations April 2009, Available at: 


\section{Columbia Undergraduate Research Journal}

https://www.un.org/ruleoflaw/files/Guidance_Note_United_Nations_Assi stance_to_Constitutionmaking_Processes_FINAL.pdf) [Accessed 12/06/20]

Harel, Amos. and Tibon, Amir.'Full Annexation or Limited Sovereignty: Netanyahu's Multiple Scenarios Have One Goal' Haaretr, 2020 available at: https://www.haaretz.com/israel-news/.premium-full-annexation-or-limitedsovereignty-netanyahu-s-multiple-scenarios-have-one-goal-1.8932510

[Accessed 12/06/20]

Hermann et al. "Israel Democracy Index 2018," Israel Democracy Institute, Jerusalem, 2018, vol 31, 2018 https://en.idi.org.il/publications/25031. [Accessed, 09/06/20]

Hovel, Revital. 'Justice Minister: Israel Must Keep Jewish Majority Even at the Expense of Human Rights' Haaretz, 2018, available at: https://www.haaretz.com/israel-news/justice-minister-israel-s-jewishmajority-trumps-than-human-rights-1.5811106 [Accessed, 09/06/20]

Inter-Agency Task Force on Israeli Arab Issues 'Basic Law: Israel As The Nation-

State Of The Jewish People: Discourse And Implications For Arab Citizens Of Israel', 2018, Available at:

$<$ https://www.iataskforce.org/sites/default/ files/resource/resource1624.pdf> [Accessed 7 June 2020].

Iraqi, Amjad. 'The redundancy of Israel's 'Jewish Nation-State Law' +972 magazine, 2017, available at: https://www.972mag.com/the-redundancy-of-israelsjewish-nation-state-law/ [Accessed 07/06/2020]

Karatnycky, Adrian. "The Decline Of Illiberal Democracy". Journal Of Democracy, vol 10, no. 1, 1999, pp. 112-125. Project Muse, doi:10.1353/jod.1999.0011.

Khamaisi, Rassem. 'Israeli use of the British Mandate planning legacy as a tool for the control of Palestinians in the West Bank' Planning Perspectives 12(3), 1997 pp.321-340.

Kimmerling, B. (1989) 'Boundaries and Frontiers of the Israeli Control System: Analytical Conclusions In The Israeli State and Society', ed. Baruch Kimmerling, 265-284. Albany, NY: SUNY Press pp.265-284

Knesset.gov.il 'Basic Law: Israel- The Nation State of the Jewish People' Unofficial translation by Dr. Susan Hattis Rolef available at:

https://knesset.gov.il/laws/special/eng/BasicLawNationState.pdf 2018,[Accessed 07/06/2020]

Knesset.gov.il 'Basic Law: Human Dignity and Liberty' Available at: https://www.knesset.gov.il/laws/special/eng/basic3_eng.html ,1992

[Accessed 10/12/2020]

Kontorovich, Eugene. (2020) 'A Comparative Constitutional Perspective on Israel's Nation-State Law' Israel Studies vol 25, no. 3, 2020 pp.137-152

Kupchan, Charles. 'Democracy First' Foreign Affairs vol 77, no. 3, 1998 


\section{Columbia Undergraduate Research Journal}

Lis, Jonathan. 'How a Bill to Override Israel's Top Court Would Help Netanyahu' Haaretz, 2019 available at: https://www.haaretz.com/israel-news/.premiumhow-would-a-broader-high-court-override-bill-help-netanyahu-1.7237773 [Accessed, 09/06/20]

Locker-Biletzki, Amir., (2017) 'Colonialism and imperialism in Communist thinking in Palestine/Israel 1919-1965’ Settler Colonial Studies, vol 8, no.3, 2017 pp.384399.

Loughlin, Martin., 'The Contemporary Crisis of Constitutional Democracy' Oxford Journal of Legal Studies, vol 39, no.2, 2019, pp.435-454.

Mossawa 'The Jewish Nation-State Bill And Its Implications For Democracy, Human Rights, And The Middle East Peace Process', 2017 available at: https:/ /dinonline.info/pdf/ms8.pdf [Accessed 27/12/2020]

Peled, Yoav. and Navot, Doron., (2005) 'Ethnic Democracy Revisited: On the State of Democracy in the Jewish State' Israel Studies Review, vol 20, no.1, 2005

Peled, Yoav., The Challenge Of Ethnic Democracy. Abingdon: Routledge, 2014.

Pileggi, Tamar. '30,000 oppose Nation-State Law at Arab-led Tel Aviv rally; Palestinian flags fly' The Times of Israel, 2018, available at: https://www.timesofisrael.com/palestinian-flags-fly-at-arab-led-rally-in-telaviv-against-nation-state-law/ [Accessed 27/12/2020]

Huntington, Samuel., 'Democracy's Third Wave' Journal of Democracy vol 2, no.2, 1991, pp.12-34.

Shapiro, Yonathan. Democracy in Israel, 1997, Ramat Gan, Israel: Massada (Hebrew)

Smooha, Samuel., 'The model of ethnic democracy: Israel as a Jewish and democratic state' Nations and Nationalism, vol 8, no. 4, 2002 pp.475-503.

Smooha. Samuel. 'Minority status in an ethnic democracy: The status of the Arab minority in Israel' Ethnic and Racial Studies vol 13, no. 3, 1990

Spanish constitution, 1978, available at: http://www.congreso.es/portal/page/portal/Congreso/Congreso/Hist_No rmas/Norm/const_espa_texto_ingles_0.pdf

Unger, Roberto Mangabeira., 'The Critical Legal Studies Movement' Harvard Law Review, vol 96, no. 3, 1983, p.561.

Waxman, Don and Peleg, Ilan. 'The Nation-State Law and the Weakening of Israeli Democracy’ Israel Studies, vol 25, no. 3, 2020, p.185.

Wootliff, Raoul. 'Bill conditioning arts funding on 'loyalty' clears first Knesset hurdle' Times of Israel, 2018, available at: https://www.timesofisrael.com/billconditioning-arts-funding-on-loyalty-clears-first-knesset-hurdle/ [Accessed $27 / 12 / 2020]$

Yakobson, Alexander. 'Jewish Nation-State, Not This Law' Israel Studies vol 25, no. 3, 2020, pp.167-184 


\section{Columbia Undergraduate Research Journal}

Yiftachel, Oren., "Ethnocracy" and Its Discontents: Minorities, Protests, and the Israeli Polity' Critical Inquiry, vol 26, no. 4, 2000, pp.725-756.

Zakaria, Fareed. (1997) 'The Rise of Illiberal Democracy' Foreign Affairs, vol 76, no. 6, 1997, pp.22-43 available at:

https://www.jstor.org/stable/20048274?seq=1\#metadata_info_tab_content s [Accessed 27/12/2020]

Zakaria, Fareed., The Future Of Freedom, 2007,. New York: W.W. Norton \& Co. 